\title{
Determinan Asupan Makanan Usia Lanjut
}

\section{Food Intake Determinant Factor among Elderly}

\author{
Yuli Amran, Riastuti Kusumawardani, Nita Supriyatiningsih
}

Fakultas Kedokteran dan Ilmu Kesehatan Universitas Islam Negeri Syarif Hidayatullah Jakarta

\begin{abstract}
Abstrak
Berdasarkan data Kementerian Sosial, jumlah usia lanjut (usila) di Indonesia tahun 2004 tercatat 16.522.311 jiwa dan 3.092.910 jiwa atau sekitar $20 \%$ adalah usila terlantar. Nutrisi yang kurang pada usila berdampak pada kesehatan sehingga relatif mudah terjangkit penyakit infeksi dan gangguan zat gizi. Selain itu, asupan makanan berhubungan dengan depresi, jumlah gigi, gangguan gigi, penggunaan obat, penyakit, dukungan sosial seperti kunjungan keluarga atau orang terdekat, dan rasa makanan. Tujuan penelitian ini adalah mengetahui berbagai faktor yang berhubungan dengan asupan makanan pada usila. Penelitian menggunakan desain studi cross sectional dilakukan terhadap 58 orang usila di Panti Sosial Tresna Werdha Budi Mulia 01 Cipayung pada periode bulan Mei-Juni tahun 2010. Metode analisis multivariat digunakan untuk melihat faktor dominan yang berpengaruh terhadap asupan makanan. Sekitar $62,1 \%$ usila di panti sosial yang diteliti mempunyai asupan makanan yang kurang. Berdasarkan hasil analisis multivariat, makanan, penyakit, dan jumlah gigi merupakan faktor yang paling dominan memengaruhi asupan makanan pada usila.

Kata kunci: Asupan makanan, lanjut usia
\end{abstract}

\begin{abstract}
Abstrack
Base on Ministry of Sosial Welfare, the number of elder in Indonesia 2004 was recorded 16.522 .311 and 3.092 .910 or about $20 \%$ were negleted elders. Poor nutrition will impact on the health of the elders that directly related the infectious disease and the level of food intake. Besides, food intake is also associated with depression, the number of theet, the dental disorders, drug use, diseases, social support include the visit of the family or the people around them, and the taste of the food. The objective of study is to describe the factors that associated with food intake on the elders. This study that was conducted in Mei-June 2010 used cross sectional design. The sample that was suitable with criteria used in this study is about 58 people. The study used multivariate analysis to know the dominant factors that affected food intake. The result showed that $62,1 \%$ of elders in Panti Sosial
\end{abstract}

Tresna Werdha Budi Mulia 01 Cipayung has less food intake. Based on the results, the diseases, depression, number of the teeth, and taste of the food are associated with food intake of the elders.

Key words: Food intake, erderly

\section{Pendahuluan}

Jumlah penduduk usia lanjut (usila) di dunia diperkirakan hampir mencapai 600 juta orang dan diproyeksikan menjadi 2 milyar pada tahun 2050. Berdasarkan data Kementerian Sosial, di Indonesia pada tahun 2004, jumlah usila tercatat 16.522 .311 jiwa dan 3.092 .910 jiwa atau sekitar $20 \%$ adalah usila terlantar. Dengan banyaknya usila yang terlantar dan jumlah populasi usila yang naik dengan cepat maka cepat atau lambat akan menjadi masalah bila tidak dipersiapkan mulai sekarang.

Salah satu bentuk perhatian pemerintah menghadapi permasalahan usila adalah pendirian Panti Sosial Tresna Werdha. ${ }^{1}$ Namun, Panti Sosial Tresna Werdha tersebut tidak serta merta menghilangkan semua permasalahan usila. Salah satu masalah tersisa yang berhubungan dengan kesehatan adalah masalah gizi. Penelitian yang dilakukan di 5 Panti Sosial Tresna Werdha pemerintah di Daerah Khusus Ibu Kota (DKI) Jakarta menemukan jumlah usila yang mengalami kekurangan gizi adalah 32,97\%.2 Panti Sosial Tresna Werdha Budi Mulia 01 Cipayung adalah panti pemerintah tertua di DKI Jakarta yang didirikan pada tahun 1968. Berdasarkan penelitian sebelumnya, dilaporkan jumlah usila yang mengalami

Alamat Korespondensi: Yuli Amran, FKIK UIN Syarif Hidayatullah Jakarta, Il. Kertamukti, Pisangan, Ciputat 15412, Hp. 081381723823.

e-mail: yuli.amran@uinjkt.ac.id 
malnutrisi adalah $50,7 \%$ dan pada tahun 2009 mengalami peningkatan menjadi $70,6 \%$.

Ada 2 penyebab langsung gizi kurang meliputi penyakit infeksi dan tingkat asupan makanan. Artikel ini terfokus pada berbagai faktor yang memengaruhi asupan makanan pada usila antara lain depresi, jumlah gigi, gangguan gigi, penggunaan obat, penyakit penyerta, dukungan sosial meliputi kunjungan, dan cita rasa makanan. ${ }^{3-5}$ Penelitian bertujuan untuk mengetahui berbagai faktor yang berhubungan dengan asupan makanan usila di Panti Sosial Tresna Werdha Budi Mulia 01 Cipayung tahun 2010.

\section{Metode}

Penelitian kuantitatif dengan desain studi cross sectional dilakukan di Panti Tresna Werdha Budi Mulia 01 Cipayung Jakarta pada bulan Mei 2010. Populasi dalam penelitian ini adalah seluruh usila penghuni Panti Sosial Tresna Werdha Budi Mulia 01 Cipayung sejumlah 108 orang. Kriteria inklusi adalah usila yang masih dapat diajak berkomunikasi, tidak sedang terbaring sakit, dan tidak mengalami gangguan jiwa. Jumlah sampel yang memenuhi kriteria dan dapat digunakan dalam penelitian berjumlah 58 orang. Variabel yang diamati adalah konsumsi makanan menggunakan metode food weighing dan diolah menggunakan Nutrisurvey 2007. Pengukuran dilakukan pada 2 hari tidak berurutan yang merupakan kombinasi hari dalam seminggu. Variabel depresi diukur dengan metode Geriatric Depression Scale-15 yang berisi 15 pertanyaan terstruktur. Kondisi gigi diukur melalui pemeriksaan gigi oleh perawat gigi.

Hasil pemeriksaan berupa jumlah gigi asli dan gangguan gigi yang diderita usila. Variabel kunjungan didapatkan dari wawancara dengan usila berupa kunjungan yang dapat membuat usila menjadi senang. Penggunaan obat diketahui dari hasil wawancara kepada perawat panti yang memberikan obat kepada seluruh usila dan observasi jenis obat yang mempunyai efek samping menurunkan nafsu makan yang dikonsumsi usila. Sementara variabel cita rasa makanan diukur melalui wawancara dengan usila tentang cita rasa makanan yang disajikan petugas panti. Selain data primer, penelitian juga menggunakan data sekunder berupa catatan medis yang tersedia di panti untuk mengetahui penyakit penyerta dan obat yang dikonsumsi.

\section{Hasil}

\section{Asupan Makanan Usia Lanjut}

Makanan dan pola makan yang sehat dapat menjamin usila untuk hidup lebih sehat, tetap aktif dalam waktu yang lama, membantu melindungi diri dari penyakit, dan mempercepat penyembuhan bila terkena sakit. Namun, sebagian besar usila mempunyai tingkat asupan makanan yang kurang yaitu $62,1 \%$.
Asupan makanan yang kurang pada usila dipengaruhi oleh beberapa faktor meliputi faktor penyakit penyerta, depresi, gangguan gigi, kunjungan, penggunaan obat, cita rasa makanan, serta jumlah gigi (Tabel 1 dan Tabel 2). Hasil analisis menunjukkan bahwa faktor-faktor yang terbukti berhubungan dengan asupan makanan pada usila adalah penyakit penyerta, depresi, cita rasa makanan, dan jumlah gigi. Untuk mengetahui faktor yang paling dominan dilakukan analisis multivariat.

Variabel yang paling berpengaruh adalah cita rasa makanan, terlihat pada nilai odds ratio (OR) yang lebih besar dibandingkan variabel lain yaitu 6,87 kali. Hasil analisis lebih lanjut, ketiga faktor ini mampu menjelaskan variasi variabel asupan makanan sebesar $34,1 \%$. Selebihnya sekitar 65,9\% dijelaskan oleh variabel lain yang tidak diteliti (Tabel 3).

\section{Pembahasan}

\section{Gambaran Asupan Makanan Usia Lanjut}

Asupan makanan usila di Panti Sosial Tresna Werdha Budi Mulia 01 Cipayung tergolong kurang lebih banyak dibandingkan yang mempunyai asupan gizi cukup. Hasil penelitian ini didukung oleh beberapa penelitian lain yang juga dilakukan di Panti Sosial Tresna Werdha yang menunjukkan bahwa kebanyakan usila mempunyai asupan makanan kurang dibandingkan asupan makanan (energi) cukup.2,4 Pemenuhan gizi usila tidak hanya dilihat dari asupan konsumsi energi dan protein, tetapi juga perlu diperhatikan asupan vitamin dan mineral. Kebutuhan vitamin dan mineral bagi usila penting untuk membantu metabolisme zat gizi yang lain.

Defisiensi vitamin E dapat menurunkan kemampuan daya tahan tubuh secara menyeluruh. Kekurangan vitamin B1 sering terjadi pada usila dengan gejala muncul gangguan sistem pencernaan berupa penyerapan buruk, sembelit, peka atau tidak tahan bahan makanan tertentu, dan hilangnya nafsu makan. Kekurangan vitamin B6 menimbulkan gejala depresi dan gangguan kulit (dermatitis). Kekurangan vitamin $\mathrm{C}$ berdampak pada berkurangnya fungsi tubuh untuk mencegah infeksi, serta menurunnya kerja enzim sebagai faktor penyerap dan penggunaan zat gizi lain. ${ }^{6}$ Untuk mengatasi hal tersebut, pihak panti memberikan suplemen vitamin B1, B2, B6, B12, dan vitamin $C$ sehingga dapat menutupi kekurangan yang didapat dari asupan makanan walau sebenarnya cara ini belum maksimal untuk mencukupi zat gizi usila di panti.

\section{Faktor-faktor yang Berhubungan \\ Penyakit Penyerta}

Peningkatan usia menyebabkan orang menjadi rentan terhadap serangan penyakit sehingga menyebabkan keadaan gizi yang buruk. Berdasarkan hasil penelitian diketahui sebagian besar usila dengan penyakit penyerta mempunyai asupan makanan yang kurang. Hasil uji sta- 
Tabel 1. Faktor yang Berhubungan dengan Asupan Makanan Usila

\begin{tabular}{|c|c|c|c|c|c|}
\hline Variabel Independen & Kategori & $\begin{array}{c}\text { Asupan Kurang } \\
(\%)\end{array}$ & $\begin{array}{l}\text { Asupan Cukup } \\
(\%)\end{array}$ & OR & Nilai $p$ \\
\hline \multirow[t]{2}{*}{ Penyakit penyerta } & Ada & 85 & 15 & $5,667(1,442-22,577)$ & $0,011^{*}$ \\
\hline & Tidak ada & 50 & 50 & & \\
\hline \multirow[t]{3}{*}{ Depresi } & Berat & 92,3 & 7,7 & $0,103(0,012-0,896)$ & $0,036^{*}$ \\
\hline & Ringan & 50,0 & 50,0 & $1,231(0,362-4,182)$ & \\
\hline & Normal & 55,2 & 44,8 & & \\
\hline \multirow[t]{2}{*}{ Gangguan gigi } & Ada & 60,8 & 39,2 & $0,620(0,11-3,509)$ & 0.698 \\
\hline & Tidak ada & 71,4 & 28,6 & & \\
\hline \multirow[t]{2}{*}{ Kunjungan } & Tidak ada & 64,4 & 35,6 & $1,154(0,445-5,420)$ & 0,529 \\
\hline & Ada & 53,8 & 46,2 & & \\
\hline \multirow[t]{2}{*}{ Penggunaan obat } & Ya & 50,0 & 50,0 & $0,533(0,148-1,926)$ & 0,505 \\
\hline & Tidak & 65,2 & 34,8 & & \\
\hline \multirow[t]{2}{*}{ Cita rasa makanan } & Rendah & 71,4 & 28,6 & $4,167(1,238-14,022)$ & $0,032^{*}$ \\
\hline & Tinggi & 37,5 & 62,5 & & \\
\hline
\end{tabular}

Keterangan : *bermakna

Tabel 2. Distribusi Frekuensi Jumlah Gigi Usila

\begin{tabular}{lccccc}
\hline Variabel & Rata-rata & Median & SD & Minimal - Maksimal & Nilai p \\
\hline Jumlah gigi & 10,43 & 10 & 7,607 & $0-23$ & $0,047^{*}$ \\
\hline
\end{tabular}

Tabel 3. Analisis Multivariat

\begin{tabular}{|c|c|c|c|c|}
\hline Variabel & Kategori & B & Nilai $p$ & OR $(95 \% \mathrm{CI})$ \\
\hline Penyakit penyerta & $\begin{array}{l}\text { Ada } \\
\text { Tidak ada }\end{array}$ & 1,504 & 0,050 & $4,498(1,002-20,190)$ \\
\hline Cita rasa makanan & $\begin{array}{l}\text { Rendah } \\
\text { Tinggi }\end{array}$ & 1,927 & 0,013 & $6,870(1,500-31,453)$ \\
\hline Jumlah gigi & & 0,098 & 0,042 & $1,103(1,004-1,212)$ \\
\hline
\end{tabular}

tistik juga menunjukkan hubungan antara penyakit penyerta dengan asupan makanan usila. Pada proses penuaan terjadi penghilangan secara perlahan kemampuan jaringan untuk memperbaiki diri atau mengganti fungsi normal sehingga tidak dapat bertahan terhadap infeksi serta memperbaiki kerusakan yang diderita. ${ }^{7}$ Berbagai kondisi medis umum pada usila seperti penyakit gastrointestinal, sindrom malabsorpsi, infeksi akut dan kronis, serta hipermetabolisme sering menyebabkan anoreksia sehingga berpengaruh terhadap asupan makanan. Hasil penelitian lain menyatakan bahwa konsumsi zat gizi lebih rendah pada usila yang mempunyai masalah fisiologis. ${ }^{8}$ Kondisi kesehatan seperti artritis dan osteoporosis dapat mengakibatkan penurunan asupan energi dan protein artritis. Selain itu, pengendalian nafsu makan sangat kompleks, tetapi jelas bahwa sinyal fungsi gastrointestinal membawa perubahan nafsu makan dan asupan makanan pada usila. ${ }^{3,8}$

\section{Depresi}

Berbagai persoalan hidup yang mendera usila sepan- jang hayat seperti konflik dengan keluarga atau anak dan tidak mempunyai keturunan yang dapat merawat dapat memicu terjadinya depresi. Penelitian ini diketahui bahwa usila yang mempunyai depresi berat sebagian besar mempunyai asupan makan kurang. Hasil uji statistik juga menunjukkan bahwa ada hubungan yang signifikan antara depresi dengan asupan makanan usila. Kontak dengan sesama usila penghuni Panti Werdha Budi Mulia 01 Cipayung tidak jarang menimbulkan keributan atau pertengkaran di antara sesama penghuni panti. Hal ini menimbulkan gangguan hubungan sosial dengan sesama. Penurunan kontak sosial merupakan salah satu faktor pemicu terjadinya depresi. Penelitian lain menunjukkan sebanyak $47,0 \%$ usila menyatakan bahwa pengaruh rasa sedih, khawatir, dan kesepian membuat mereka malas makan. ${ }^{10}$ Gejala depresi meningkat di kalangan usila perempuan yang memengaruhi asupan gizi. Depresi menyebabkan hilangnya nafsu makan dan kenikmatan makanan, serta kesulitan persiapan makanan. Makanan yang kurang bervariasi juga akan menambah hilangnya selera makan. 


\section{Gangguan Gigi}

Terdapat penelitian yang menunjukkan bahwa 30,6\% usila yang mempunyai gangguan gigi berpengaruh terhadap kebiasaan makan. ${ }^{10}$ Selain itu, terdapat pula hasil penelitian yang menyatakan bahwa masalah gigi terkait dengan penurunan asupan makanan harian sekitar 5\% dari total energi yang dikonsumsi oleh usila dengan masalah gigi dibandingkan dengan usila tanpa masalah gigi. ${ }^{11}$ Pada penelitian ini, usila yang mengalami gangguan gigi mempunyai asupan makanan kurang hampir sama banyak dengan usila yang tidak mempunyai gangguan gigi. Hal ini menunjukkan bahwa proporsi yang mempunyai asupan makanan kurang antara yang mengalami gangguan gigi dengan tidak mengalami gangguan gigi tidak terlalu berbeda. Berdasarkan hasil uji statistik menunjukkan tidak ada hubungan antara gangguan gigi dengan asupan makanan usila.

Tidak ada hubungan antara gangguan gigi dengan asupan makanan diasumsikan dapat terjadi karena proses makan tidak hanya dipengaruhi oleh gangguan gigi tetapi kondisi mulut juga berpengaruh terhadap proses makan. Mulut kering atau sakit pada mulut juga berpengaruh pada proses makan yang berdampak pada asupan makan usila. Sebuah penelitian menjelaskan bahwa $20 \%$ usila dengan xerostomia (mulut kering) mengeluhkan kesulitan makan makanan tertentu. ${ }^{12}$ Selain itu, ada penelitian yang menyatakan bahwa tidak hanya kondisi gigi yang berhubungan dengan kurangnya asupan gizi tetapi perlu diperhatikan juga faktor biologis seperti enzim dan hormonal yang dapat menghambat proses makan yang normal. ${ }^{2}$ Oleh sebab itu, meskipun kondisi gigi tidak mengalami gangguan, tetapi mulut usila mengalami gangguan atau kondisi enzim dan hormonal yang tidak normal dapat berpengaruh terhadap asupan makanan. Selain itu, cita rasa makanan juga terbukti berpengaruh kuat terhadap asupan makanan. Walaupun gigi tidak mengalami gangguan namun apabila cita rasa makanan kurang akan memengaruhi asupan makanan pada usila.

\section{Kunjungan}

Kemauan makan dan nafsu makan sangat dipengaruhi oleh faktor sosial. ${ }^{2}$ Dukungan sosial berkaitan dengan kesendirian yang mempunyai efek negatif pada semangat kerja, kesejahteraan, dan selera makan. ${ }^{3}$ Panti Sosial Tresna Werdha Budi Mulia 01 Cipayung merupakan salah satu tempat penampungan usila yang terlantar. Sebagian besar usila di panti tersebut merupakan usila yang sudah tidak punya keluarga atau terlantar. Dengan demikian, kunjungan keluarga yang diterima panti ini sedikit. Begitu pun dengan jumlah kunjungan sosial dari masyarakat tidak dapat dipastikan. Ditambah lagi tidak semua usila di panti tersebut menerima kunjungan sosial karena kunjungan tersebut umumnya hanya berkunjung di ruang kantor sehingga usila yang tidak mempu- nyai kemampuan berjalan atau sakit tidak dapat menemui tamu tersebut. Kunjungan sosial di Panti Sosial Tresna Werdha Budi Mulia 01 Cipayung berupa acara hiburan oleh masyarakat di kantor atau dengan mengunjungi wisma-wisma usila untuk melihat dan memberikan bantuan kepada usila lain. Tanpa mengikuti kegiatan seharian, mereka menemani usila makan. Sementara usila makan di dalam wisma masing-masing atau bahkan menghabiskan makanan di atas tempat tidur.

Penelitian ini menemukan bahwa asupan makanan kurang lebih banyak ditemui pada usila yang tidak mendapat kunjungan. Namun, banyak usila yang mendapatkan kunjungan dengan asupan makanan yang kurang. Oleh sebab itu, hasil uji statistik menunjukkan tidak ada perbedaan yang signifikan antara proporsi usila yang mengalami asupan makanan kurang pada kelompok yang mendapat kunjungan dengan yang tidak mendapat kunjungan. Penelitian ini didukung oleh penelitian lain yang menyatakan bahwa tidak ada pengaruh kehadiran orang lain dengan asupan makanan usila. ${ }^{13}$

Hal tersebut dapat saja terjadi karena banyak faktor yang memengaruhi asupan makanan pada usila. Pada penelitian ini terbukti cita rasa, penyakit penyerta, dan jumlah gigi mempunyai peran yang sangat penting terhadap asupan makanan usila. Usila yang mempunyai penyakit penyerta lebih banyak dibandingkan dengan usila yang tidak mempunyai penyakit penyerta. Selain itu, usila yang mempunyai kecenderungan individu untuk mempertahankan gigi sampai tua tidak terlalu banyak. Bahkan kira-kira $10 \%$ populasi usila kehilangan gigi. ${ }^{14}$ Dengan demikian, meskipun usila mendapatkan kunjungan sosial namun kondisi fisik mereka yang sakit dan jumlah gigi mereka sangat kurang akan memengaruhi asupan makanan, ditambah dengan cita rasa makanan yang kurang.

\section{Penggunaan Obat}

Penggunaan berbagai macam obat juga termasuk faktor yang memengaruhi status gizi usila. Penggunaan berbagai macam obat mengakibatkan semakin besar kemungkinan efek samping seperti kelemahan, pusing, diare, perubahan rasa dan nafsu makan, mual, serta sembelit. ${ }^{3}$ Obat-obatan tertentu menyebabkan penurunan berat badan dengan penurunan nafsu makan. ${ }^{15}$

Hasil penelitian terhadap penggunaan obat dengan asupan makanan pada usila di Panti Sosial Tresna Werdha menunjukkan bahwa sebagian besar responden tidak mengonsumsi obat. Usila hanya diberi obat ketika mengalami keluhan kesehatan. Dengan demikian, jumlah usila yang mengonsumsi obat khususnya obat yang mempunyai efek menurunkan nafsu makan hanya sedikit. Selain itu, hasil penelitian menunjukkan sebagian besar usila yang mempunyai asupan makanan kurang justru mereka yang tidak mengonsumsi obat. Namun jumlahnya tidak terlalu jauh berbeda dengan yang mengonsumsi 
obat. Hal ini mengindikasikan bahwa usila yang tidak mengonsumsi obat juga mempunyai selera makan yang sangat kurang. Hal ini juga didukung hasil penelitian lain yang tidak menunjukkan hubungan bermakna antara penggunaan obat dengan asupan makanan. Asupan makanan usila yang tidak mengonsumsi obat-obatan akan tetap berkurang apabila mereka mempunyai penyakit penyerta dan kehilangan gigi, ditambah dengan cita rasa makanan yang kurang.

\section{Cita Rasa Makanan}

Makanan yang mempunyai cita rasa tinggi adalah makanan yang disajikan menarik, menyebarkan bau yang sedap, dan memberikan rasa lezat. Berdasarkan hasil penelitian didapatkan bahwa sebagian besar usila yang mempunyai asupan makanan kurang menyatakan bahwa cita rasa makanan di Panti Sosial Tresna Werdha Budi Mulia 01 Cipayung tergolong rendah. Hasil uji statistik juga menunjukkan bahwa ada hubungan antara cita rasa makanan dengan asupan makanan usila. Penelitian ini sesuai dengan beberapa penelitian lain yang menunjukkan bahwa sebanyak 19,3\% usila dapat meningkatkan nafsu makan mereka dengan makan makanan kesukaan. ${ }^{10}$ Selain itu, sebuah penelitian eksperimental menyatakan bahwa dampak peningkatan rasa pada makanan selama 3 minggu dengan menyempurnakan rasa makanan menghasilkan asupan lebih besar dari beberapa makanan. ${ }^{5}$

Berdasarkan hasil uji multivariat, cita rasa makanan merupakan faktor yang paling dominan berhubungan dengan asupan makanan usila setelah dikontrol dengan penyakit penyerta dan jumlah gigi. Dengan demikian, peneliti mengasumsikan jika usila merasa bahwa makanan yang disajikan pihak panti mempunyai cita rasa makanan yang tinggi maka akan meningkatkan asupan makanan meskipun usila tersebut mempunyai penyakit penyerta atau jumlah gigi yang sedikit. Cita rasa makanan yang rendah tidak hanya dipengaruhi oleh kualitas makanan yang rendah, tetapi perlu dipertimbangkan juga penurunan fungsi fisiologis indra usila. Terjadi perubahan-perubahan pada usila termasuk adanya penurunan indra pengecap akan memengaruhi selera makan. ${ }^{16}$

\section{Jumlah Gigi}

Kehilangan gigi dapat mengganggu usila ketika makan sehingga mengurangi selera makan. ${ }^{3}$ Meskipun terdapat kecenderungan bahwa individu saat ini dapat mempertahankan giginya sampai tua, tetapi kira-kira $10 \%$ populasi tersebut mengalami kehilangan gigi. ${ }^{14}$ Berdasarkan hasil penelitian didapatkan bahwa rata-rata jumlah gigi responden sebesar 10,43 buah gigi. Hasil ini tidak jauh berbeda dengan hasil sebuah penelitian di 5 Panti Sosial Tresna Werdha DKI Jakarta yang juga menyatakan bahwa sebagian besar responden mempunyai jumlah gigi 1-10 buah gigi. ${ }^{2}$ Hasil uji statistik menunjukkan bahwa terdapat hubungan antara jumlah gigi dengan asupan makanan usila. Usila dengan jumlah gigi yang sedikit mengalami kesulitan ketika mengunyah makanan.

Suatu penelitian menyatakan 1 dari 5 usila melaporkan bahwa kondisi gigi menghambat mereka dalam memilih makanan. Selain itu, jumlah gigi asli juga terkait dengan kemampuan untuk makan makanan tertentu sehingga memengaruhi asupan gizi. ${ }^{12}$ Berdasarkan hasil uji multivariat diperoleh hasil bahwa jumlah gigi merupakan salah satu faktor besar yang berhubungan dengan asupan makanan usila setelah dikontrol cita rasa makanan dan penyakit penyerta.

\section{Kesimpulan}

Berbagai faktor yang berhubungan dengan asupan makanan usila adalah penyakit penyerta, depresi, jumlah gigi, dan cita rasa makanan. Hasil uji multivariat menunjukkan bahwa faktor yang paling dominan berhubungan dengan asupan makanan usila secara berturut-turut adalah cita rasa makanan, penyakit penyerta, dan jumlah gigi.

\section{Saran}

Kepada pemerintah disarankan untuk membuat pedoman teknis penyelenggaraan manajemen gizi institusi untuk panti werdha. Hal tersebut antara lain pemenuhan gizi sesuai angka kecukupan gizi dan penerapan diet khusus dengan penyakit tertentu serta meningkatkan sumber daya manusia di Panti Sosial Tresna Werdha seperti ahli gizi, dokter, psikiater, dan ahli gigi. Bagi instansi disarankan menyediakan makanan padat gizi dan bercita rasa tinggi untuk meningkatkan asupan gizi serta melibatkan perwakilan usila dalam menentukan siklus menu yang sesuai dengan selera usila. Untuk mengurangi kejenuhan, disarankan mengadakan rekreasi ke tempat yang menyenangkan untuk meningkatkan interaksi dengan usila penghuni Panti Sosial Tresna Werdha Budi Mulia 01 Cipayung sehingga mereka merasa diperhatikan. Usila disarankan untuk menjaga kebersihan gigi sehingga tetap bagus dan ikut berpartisipasi pada kegiatan yang diselenggarakan. Peneliti lain disarankan melakukan penelitian kualitatif untuk menggali lebih dalam permasalahan gizi pada usila. Selain itu, menggunakan variabel independen lain sebab variabel independen penelitian ini hanya mampu menjelaskan variasi variabel asupan makanan sebesar $34,1 \%$, selebihnya $(65,9 \%)$ dijelaskan oleh variabel lain yang tidak diteliti pada penelitian ini.

\section{Daftar Pustaka}

1. Maryam S, dkk. Usia lanjut dan perawatannya. Jakarta: Salemba Medika; 2008.

2. Nisa H. Faktor-faktor determinan status gizi lansia penghuni panti werdha pemerintah DKI Jakarta tahun 2004. Media Penelitian dan Pengembangan Kesehatan Litbangkes (MPPK). 2006; XVI (3): 24-34. 
3. Grosvenor, Smolin. Nutrition from science to life. Philadelpia: Hill Companies; 2002.

4. Sumiyati N. Hubungan antara tingkat konsumsi energi dan protein dengan status gizi pada lansia di panti werdha Pucang Gading Semarang. 2007 [diakses tanggal 31 Januari 2010]. Diunduh dari: http://www.digilib.unnes.ac.id.

5. Schiffman SS, Warwick ZS. Effect of flavor-enhancement of foods for the elderly on nutritional status: food intake, biochemical indices, and anthropometric measures. Physiology and Behavior. 1993; 63: 395-402.

6. Tambunan V. Gizi pada usia lanjut. 2009 [diakses tanggal 27 februari 2010]. Diunduh dari: http://www.repository.ui.ac.id.

7. Darmodjo B. Geriatri (ilmu kesehatan usia lanjut). Edisi keempat. Jakarta: Balai Penerbit Fakultas Kedokteran Universitas Indonesia; 2009.

8. Jain, Phadnis. Effect of physiogical problems on dietary intake of elderly. Indian Journal of Gerontology. 2007; 21 (1): 44-51.

9. Syamsudin. Depresi pada lansia. 2006 [diakses tanggal 16 Juni 2009]. Diunduh dari: http://www.depsos.go.id.

10. Husaini. Penelitian keadaan gizi dan faktor-faktor biomedika terhadap makanan sosiokultural dan psikologi yang mempengaruhi lanjut usia dalam laporan penelitian Bogor. Bogor: Kementerian Kesehatan Republik Indonesia; 1990.

11. Sullivan DH. Oral health problems and involuntary weight loss in a population of elderly. Journal of the American Geriatries Society. 1993; 41: 725-31.

12. Sheiham A, Stelee J. Does the condition of the mouth and teeth affect the ability to eat certain foods, nutrient, dietary intake, and nutritional status among older people? Public Health Nutritiont. 2001; 4(3): 797803 [diakses tanggal 8 Juni 2010]. Diunduh dari: http://www.journals.cambridge.org.

13. Locher JL, Ritchie CS, Roth DL, Sen B, Vickers KS, Vailas LI. Food choice among homebound older adults: motivations and perceived barries. J Nutr Health Aging. 2009; 13 (8): 659-64 [diakses tanggal 17 Juni 2010]. Available from: http://www.ncbi.nlm.nih. gov.

14. Jubhari, Eri H. Proses menua sendi temporomandibula pada pemakai gigi tiruan lengkap. Cermin Dunia Kedokteran. 2002; 137: 41-5.

15. Morley J. Symposium on 'nutrition and the elderly' protein-energy malnutrition in older subjects. 1998 [diakses tanggal 6 Juni 2010]. Diunduh dari: http://www.journal.cambridge.org.

16. Nugroho W. Keperawatan gerontik. Edisi 2. Jakarta: EGC; 2000. 